\title{
The Importance Of Entrepreneurial Competencies On The Performance Of Women Entrepreneurs In South Africa
}

Tola Zizile, University of Fort Hare, South Africa

Chimucheka Tendai, University of Fort Hare, South Africa

\begin{abstract}
The study investigated the importance of entrepreneurial competencies on the performance of women entrepreneurs in East London, South Africa. The objectives of this study were to identify key entrepreneurial competencies that influence the performance of women entrepreneurs, to establish a relationship between entrepreneurial competencies and the performance of women entrepreneurs and to suggest strategies that can be implemented to improve entrepreneurial competencies of women entrepreneurs. Both primary and secondary data source were used in this research. This research followed a quantitative research design. A self-administered questionnaire was used to collect primary data. The findings of this research showed that entrepreneurial competencies are crucial for the survival and performance of SMMEs.
\end{abstract}

Keywords: Performance; Entrepreneurial; Competencies; SMME; South Africa

\section{INTRODUCTION}

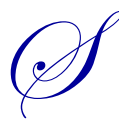
mall, Micro and Medium Enterprises (SMMEs) are recognised by policy makers as a way to improve sustainable development (Urban \& Naidoo, 2012). In South Africa, SMMEs are the backbone to the development and growth of the economy (Ayyagari, Demirguc-Kunt \& Maksimovic 2011). Current literature supports that SMMEs also contribute to economic growth, job creation, poverty elevation, and employment within disadvantaged communities. Moreover, the government of South Africa acknowledged that skills and competencies are critical factors underlying SMME performance (Peter \& Naicker, 2013) and that they can be enhanced through guidance and appropriate skills training. Mitchelmore and Rowley (2013) state that identifying and developing entrepreneurial competencies, namely, idea generation, innovative skills, envisioning opportunities, risktaking and creativity possessed by entrepreneurs who are leading successful SMMEs, may support the development of potential businesses.

It is important to study entrepreneurial competencies and to understand their importance in enhancing the performance of SMMEs; hence this study aims to explore the impact entrepreneurial competencies on the performance of women owned SMMEs.

\section{Problem Statement}

SMMEs are regarded as the driving force in creating employment and economic growth for both less and more developed countries (Peter \& Naicker, 2013). However, the survival of these SMMEs is relatively very low in South Africa (Herrington, Kew \& Kew, 2010) which has a disappointingly high number of SMMEs that fail. Various studies have shown that the majority of new SMMEs fail to survive beyond the first five years (Fatoki \& Garwe, 2010; Fatoki \& Odeyemi, 2010; Van Scheers, 2011).

Existing literature reveal that the situation is worse for women entrepreneurs as compared to their male counterparts (Chiloane-Tsoka, 2013). In society, females are perceived as not having financial ability or capability (ChiloaneTsoka, 2013), to accumulate their own personal assets, such as land and property, which in turn reduce their ability to 
raise loans. Lack of entrepreneurial competencies is said to be the main contributor to low entrepreneurial activity and the high failure rate for women entrepreneurs in South Africa (Herrington et al. 2010).

\section{OBJECTIVES}

The primary objective of this research was to investigate the importance of entrepreneurial competencies on the performance of women entrepreneurs in East London, South Africa.

The secondary objectives of this research were to:

- Establish the relationship between owners' innovation skills and the performance of women entrepreneurial ventures;

- Investigate the extent to which owners' ability to generate ideas contribute to the success of women owned enterprises;

- Determine the contribution of risk taking on the performance of entrepreneurial ventures owned by women;

- Establish the relationship between owners' creativity and growth of women owned enterprises;

- Investigate the role of envisioning opportunities in improving the performance of women entrepreneurs.

\section{HYPOTHESIS}

The hypotheses of this study are:

H1: Entrepreneurial competencies do not have an impact on the performance of women entrepreneurs in East London.

H2: There is no relationship between owners' innovation skills and the performance of women entrepreneurial ventures.

H3: The owners' ability to generate ideas has no impact on the success of women owned enterprises

H4: Risk- taking does not influence the performance of entrepreneurial ventures owned by women.

H5: There is no relationship between owners' creativity and growth of women owned enterprises.

H6: The owners' ability of envisioning opportunities does not play a role in improving the performance of women entrepreneurs.

\section{SIGNIFICANCE OF THE STUDY}

This research is important for the development of the SMME sector in South Africa, particularly in East London which is in the Eastern Cape Province. This province is the poorest in South Africa (Hendriks et al. 2016). The findings of the study are also useful for the development of female entrepreneurs. These research results will also be useful to potential and already existing entrepreneurs who intend to sustain and grow their businesses. The research results can also be useful to government, policy makers, banks and other private companies to identify priority areas in developing the SMMEs sector.

\section{LITERATURE REVIEW}

This section provides an overview of literature on SMMEs in South Africa. Women entrepreneurship is also discussed, taking into consideration their contribution and the challenges faced by women entrepreneurs. Empirical literature on entrepreneurial competencies and the performance of SMMEs is also discussed. 


\section{Overview of SMMEs in South Africa}

In South Africa, SMMEs are defined in the National Small Business Act of 1996 (amended in 2003) as "a separate and distinct business entity, including co-operative enterprises and non-governmental organisations, managed by one owner or more which, including its branches or a subsidiary, if any, is predominantly carried on in any sector or sub sector of the economy".

The National Small Business Act further categorise small businesses into five distinct groups namely; survivalist, micro, very small and medium, hence the use of the term 'SMME' for small, medium and micro-enterprises. This classification is mainly based on number of full time employees, annual revenue and also the market share.

\section{Entrepreneurship}

Mitchelmore and Rowley (2013) described entrepreneurship as a process of action by anyone to establish his or her enterprise. Thus, entrepreneurship is a creative activity, it is said to be the ability to create and build something from absolutely nothing. Entrepreneurship can also be seen as an attitude of the mind to identify and pursue opportunities, take calculated risks, and benefit by establishing business ventures. Furthermore, Ahamad, Halim and Zainal (2010) defined entrepreneurship as underlying characteristics such as traits, motives, self-images, social roles and skills which result to the development, and improved performance of the business.

\section{Entrepreneurial Competencies}

Entrepreneurial competencies are associated with the entrepreneurs' ability to be innovative, creativity, be able to identify opportunities, identify strengths and weaknesses. Ahmad, Ramayah, Wilson and Kummerow (2010) defined entrepreneurial competencies as the total ability of an entrepreneur to perform their role successfully.

Mitchelmore and Rowley (2013) suggested that entrepreneurial competencies be measured using individual level competencies, which can be classified into four main categories namely personal and relationship, business and management, entrepreneurial and human relations competencies.

Personal and relationship competencies refer to the ability to negotiate with others, and to maintain a good personal network of work contacts, developing long term trusting and loyal relationship with others (Mitchelmore \& Rowley, 2013). Business and management competencies, includes various business tasks such as managing of finance, budgeting, business operations as well as the business planning. Human relations competencies refer to the combination of human relations functions and the management in the business. It includes staff development, hiring of new staff members, leadership and motivating staff. Entrepreneurial competencies are associated with the entrepreneur's ability to be innovative, creative, be able to identify opportunities strengths and weaknesses.

\section{Women Entrepreneurship}

Women entrepreneurship is defined as a process where women or a group of women take the initiative to establish and operate a business (Xavier, Ahmad, Nor \& Yusuf, 2012; Sharma, 2013). Women entrepreneurial venture is an enterprise that is owned and managed by women having a minimum financial contribution of $51 \%$ per cent of the capital (Goyal \& Parkash, 2011). Women owned businesses provide the society with different solutions (Mehta, 2013). Women owned businesses can be in the form of beauty salons, taverns, spaza shops, and it includes those women operating as hawker and agriculture (Chiloane-Tsoka \& Mello, 2011).

\section{Challenges Faced by Women Entrepreneurs}

In South Africa, other countries there are significant issues women come across when they want to start-up an enterprise. Women business owners are disadvantaged to access capital, given their background, employment experience and cultural context in which their business operates (Mitchelmore \& Rowley, 2013). Literature states that only $2 \%$ of newly established SMMEs can access funds from financial institutions. However, a large percentage of (75\%) applications by SMMEs are rejected in South Africa. This may imply that without finance a business may not 
be able to survive in the market (Fatoki \& Garwe, 2010). All these factors play a significant role in the survival and growth of a business. Chiloane-Tsoka, (2013) identified a few factors which affect women entrepreneurs. According to this researcher one of the major stumbling block to women entrepreneurs' success in South Africa is inaccessibility or lack of finance, lack of financial knowledge, lack of entrepreneurial skills and knowledge, traditional discrimination, and lack of a business record. Earlier research indicates that women -owned businesses seem to have less growth in their business (Brijlal, Naicker \& Peter, 2013). Dafna, (2008) revealed that most women entrepreneurs are less successful in turning their managerial performance into profitable successful enterprise.

In a nutshell, business creation in the competitive world has created greater challenges for women than men to undertake entrepreneurial activity (Viju, 2010). Lack of finance, traditional discrimination, lack of entrepreneurial skills and knowledge, lack of business record, regulations and regulatory environment have become the major obstacles that women business owners are the major limiting factors to their success.

\section{$\underline{\text { Lack of Finance }}$}

It becomes a problem to run a business when there are insufficient finances available, this may even cause a delay on business growth if there is no proper financing available (Mbonyane \& Ladzani, 2010). For instance, most South African women entrepreneurs contribute to the rural economy. A significant number of women in South Africa do not own assets such as land to be used as collateral security; hence they experience hardships when acquiring financing to operate their own businesses (Mandipaka, 2014).

\section{$\underline{\text { Traditional Discrimination }}$}

Traditional discrimination contributes to women's inability to access funds, therefore lack of funds. Although the government has initiatives to support women entrepreneurship, it seems as women are still discriminated against on the basis of gender and race (Chiloane-Tsoka, 2013).

\section{Lack of Entrepreneurial Skills and Knowledge}

Education plays a critical role in the establishment of any businesses, not only does it assist in the thinking skills but it also helps to grasp business planning, accounting and management. Education presents a major challenge for women business owners. The situation is worse in developing countries where less educated females are less likely to start new businesses, due to lack of knowledge. Thus, lower levels of education can contribute to lower survival rates of women-owned SMMEs.

\section{$\underline{\text { Lack of Business Record }}$}

Kimwolo, Saina and Cheserek (2012) points out that female applicants lack a track record in financial management and that may cause difficulties in their loans being approved by financial institutions. For banks to grant loans, they require a credit record and most female entrepreneurs lack such a credit record.

\section{Contributions of SMMEs}

Globally, scholars and policy makers view SMMEs as an ideal way to promote sustainable development (Maloka, 2013). It has been revealed that SMMEs account for a greater part of businesses in South Africa. SMMEs contribute significantly to private sector gross domestic product, poverty alleviation, employment as well as economic growth.

Mmbengwa et al. (2012) point out that SMMEs have introduced innovative products and services resulting in the creation of employment. Mandipaka (2014) noted that over the past 12 years in South Africa women have been more active in policy making and government, with $37 \%$ of parliamentarians and national cabinet being females. 


\section{Entrepreneurial Competencies and Performance}

Entrepreneurial competencies contribute significantly to any firm's performance and growth (Mitchelmore \& Rowley, 2010). For firms to compete successfully both locally and globally, SMME owners must be equipped with strong entrepreneurial competencies. Entrepreneurial competencies are carried out by individuals, who begin and grow their businesses. In order for SMMEs to survive and be successful in today's competitive and rapidly changing environment, SMMEs need to continuously enhance their entrepreneurial competencies (Song \& Kee, 2013).

There are many factors associated with SMMEs success. Previous studies have indicated that entrepreneurial actions and inactions are critical factors affecting the growth of an enterprise. Camuffo, Gerli and Gubitta (2012) argue that it is essential that SMMEs owners have diverse skills, knowledge, imagination, creativity, and the ability to identify opportunities. These are important factors which affecting SMMEs firms performance not only at in an early stage but later as well (Camuffo et al. 2012). Recent research has shown that entrepreneurial competencies are crucial for the success of an enterprise.

Mitchelmore and Rowley (2013) suggest that a key element of business success is either the presence or absence of strategic planning. Furthermore, strategic planning is defined as a continuous process of monitoring and evaluating strategic goals of the business. A strategic goal entails the business goals (vision, mission and objectives), such as identifying long term and short term issues, problems and opportunities (Mitchelmore \& Rowley, 2013).

This is evidence that strategic planning leads to an increase in firm performance. Furthermore, by neglecting strategic planning a firm might not achieve its full performance in terms of profitability and growth potentials, this may place their survival at risk. Various studies in literature support that strategic planning is more common in better performing SMMEs. When a firm engages in strategic planning there is likely to be an increase in return on assets, sales growth, profit and employee growth.

In review of literature Michelmore \& Rowley (2013) identifies five competencies as entrepreneurial competencies. These were innovative skills, risk taking, idea generation, envisioning opportunities and creativity.

\section{Innovative Skills}

Innovative skills are linked to superior firm performance. Innovativeness allows organizations to adapt to dynamic and increase market environments and survive. Innovativeness is associated with new product development, ideas or processes in the organization (Phan, Zhou \& Abrahamson, 2010). Innovativeness is related to achieving of maintaining competitive advantages; it also enhances constant adoption and facing threats but also a way to explore new opportunities (Arroyo, Feuntes \& Bojica, 2012).

According to Toner (2011) innovation is a process. It is the implementation of a new or improved product or service or delivery method, it may include changes in equipment and software. The benefit of innovation in an enterprise is that it decreases unit costs of production, to increase quality, or produce new or improved quality products.

Previous studies found that there is a positive relationship between innovation skills and firm performance. Innovativeness generates unique performance in a firm and contributes greatly to economic growth. In addition, Santandreu-Mascarel, Garzon, and Knorr (2013) defined entrepreneurship as the ability and willingness to be creative, an implementation by introducing new products and services.

Furthermore, another aspect of innovation can be in terms of marketing. Marketing innovation is a new marketing method involving changes in an already existing product design or packing, pricing and product promotion. Marketing innovation seeks to open up new markets, or positioning the business product on the market, also with the aim of increasing the firms' sales (Toner, 2011).

Risk-Taking 
Botha and Nyanjam, (2011) defined risk- taking as a person who takes the risk of profit or loss of business, some authors view risk taking as an entrepreneurship element. Some say that it involves the willingness of the entrepreneur to pursue opportunities that have a reasonable potential of producing loss or it can be a calculated risk taking that involves the willingness of the entrepreneur to pursue opportunities that might have a positive effect on the business. Risk is inherent in the day to day operations of any business. Every decision made by the management involves risk (Fortkamp \& Staffas, 2012).

\section{Idea Generation}

Idea generation is defined as the process of brainstorming. It is said to be the fundamental aspect in the process of generating new sustainable business opportunities. Analysing idea generation in an entrepreneurial perspective, it refers to the discovery of new business ideas or the development of an already existing idea into a more feasible business concept over a period of time. (Du Toit, Erasmus \& Strydom, 2010). An example of idea generation would include a proposal, business plan or an opinion. The benefit of idea generation is that it gives the entrepreneur greater chances of recognizing opportunities.

\section{Envisioning Opportunities}

It is the ability of a person to seize unusual opportunities to start-up a business. This person is opportunity seeking and innovative. This person wants to expand the business into new areas. He or she seizes the opportunities in obtaining, equipment, financing, land space or assistance.

\section{Creativity}

Creativity is stated to be the starting point of innovation, generating new ideas, and which set into motion a series of new concepts (Phan, Zhou \& Abrahamson, 2010; Hansen, Lumpkin \& Hills, 2011). It is viewed as the process in which something new comes into existence. Another aspect of creativity is that not all innovations are creative, some innovations may be adapted just to make changes to already existing products or services (Pretorius, Millard \& Kruger, 2005).

\section{Performance of SMMEs}

There has been no agreement with searchers on the appropriate measure of performance (Mahmood \& Hanafi, 2013) However, previous researches have suggested that performance measures include level of sales and growth, increase in size, scale of operation, creation of employment, and an improved economy. The most used measures of performance in literature include profitability, sales, growth in employees, and survival. However, recent study conducted by Fakoki and Machirori (2013) has concluded that performance may be measured directly, using financial and non-financial measures. Financial measures are the results of firm operations in terms of profitability. Financial measures are also known as objective measure because they can be measured individually (Amoah-Mensah, 2013). Non-financial measure is also referred to as subjective performance measure of performance. Non-financial measure is considered as intangible assets of the firm such as organisation reputation, loyalty and customer satisfaction (Machirori, 2012).

\section{Resource Based View and the Competency Based View}

The resource based view and the competence based view form the theoretical basis for this study. In terms of the resource based view, small firms need to be continuously analysed from the resources they have, the capabilities developed, the entrepreneurial competencies attained as well as the competitive advantage developed, whether it can be sustained or not. The firm depends strongly on the entrepreneur and the choices of strategy he or she makes (Brisk, 2002).

In line with the competence based view, competency is defined as the ability of an individual to do a job properly. Researchers view competence as a combination of knowledge, cognitive skills, behaviour, and values used to enhance 
performance. Taatila (2010) recently revealed that successful entrepreneurs should be creative, risk-taking, and innovation to be able to respond to the dynamic nature of the external environment.

\section{RESEARCH METHODOLOGY}

Both primary and secondary data were used to conduct this research. Primary data was collected using selfadministered questionnaires. Self-administered questionnaires were used because they have a relatively high response rate compared to alternative methods such as mail surveys. The questionnaire was pre-tested before it was used to collect data. Data was collected from women who own SMMEs in East London, South Africa. The researchers used simple random sampling, a probability sampling technique in which each element has a known and equal chance of being selected. The sample size for the study was 200 respondents and was calculated using Raosoft (2011) sample size calculator. The researchers were careful in respecting the rights of respondents and applied for ethical clearance from the University of Fort Hare's Research Ethics Committee.

\section{RESULTS AND DISCUSSIONS}

A sample of 200 respondents was used in this study. Out of 200 questionnaires that were distributed, 145 questionnaires were completed and returned by the respondents giving a $72.5 \%$. All respondents in this study were females. Of the respondents, $35 \%$ were between the ages 20 to 30 years, $32 \%$ of the respondents were between the ages $31-40$ years, $26 \%$ were between the ages $41-50$ years and only $8 \%$ were aged above 50 years. It can therefore be said that the majority of women entrepreneurs in East London fall below the age of 40 years. This is supported by Peters (2013) who stated that females are starting businesses at a younger age compared to their male counterparts. Most of the respondents had at least a completed secondary school.

Of the respondents, $46 \%$ were black, $17 \%$ white, $17 \%$ coloured and other races constituted $20 \%$. It can be said that most of the respondents in this study can be classified as black. $35 \%$ businesses had been operating for a period less than 5 years, $40 \%$ had been operating for a period between 5 to 9 years and $26 \%$ had been operating for 10 years or more.

Four main legal forms of business ownership were selected by respondents with the majority either operating a partnership or operating as sole traders. Others $(22 \%)$ were still operating close corporations while only $24 \%$ were operating companies. $28 \%$ of the respondents were from the services sector, $11 \%$ from manufacturing sector, $46 \%$ from trading sector and $15 \%$ were from the construction industry.

\section{TESTING HYPOTHESES}

The study at hand was conducted to investigate the importance of entrepreneurial competencies on the performance of women entrepreneurs in East London, South Africa. The hypotheses of this study were tested statistically and the results are as follows.

H1: Entrepreneurial competencies do not have an impact on the performance of women entrepreneurs in East London. A Chi-square test was conducted for this hypothesis and the results are presented in Table 1.

Table 1. Chi-Square tests for hypothesis 1

\begin{tabular}{l|c|c|c}
\hline & Value & Df & Asymp. Sig. (2-sided) \\
\hline Pearson Chi-Square & $65.669^{\mathrm{a}}$ & 12 & .000 \\
\hline Likelihood Ratio & 50.419 & 12 & .000 \\
\hline Linear-by-Linear Association & 12.070 & 1 & .001 \\
\hline N of Valid Cases & 144 & & \\
\hline
\end{tabular}


From the results presented on Table 1, a Chi-square value 65.669 (with 1 degree of freedom) was observed. A p-value $=0.000$ which is less than 0.05 was also observed. Since the p-value is less than 0.05 , the null hypothesis is rejected and we conclude that entrepreneurial competencies have an impact on the performance of women entrepreneurs.

It was important to also test the strength of this association. Phi and Cramer's V tests for the strength of association were conducted and the results are presented in Table 2.

Table 2. Symmetric measures

\begin{tabular}{l|l|c|c}
\hline \multicolumn{2}{|c|}{} & Value & Approx. Sig. \\
\hline \multirow{2}{*}{ Nominal by Nominal } & Phi & .675 & .000 \\
\cline { 2 - 4 } & Cramer's V & .390 & .000 \\
\hline N of Valid Cases & & 144 & \\
\hline
\end{tabular}

Based on Phi, we can observe that the strength of association between the variables is strong $(0.675=67.5 \%)$. Table 2 illustrates that there is a strong relationship between entrepreneurial competencies and the performance of women entrepreneurs.

H2: There is no relationship between owners' innovation skills and the performance of women owned entrepreneurial ventures.

A Chi-square test was conducted to assess the association between owners' innovation skills and the performance of women owned entrepreneurial ventures. These results are presented in Table 3.

Table 3. Chi-Square tests for hypothesis 2

\begin{tabular}{|c|c|c|c|}
\hline & Value & Df & Asymp. Sig. (2-sided) \\
\hline Pearson Chi-Square & $71.371^{\mathrm{a}}$ & 15 & .000 \\
\hline Likelihood Ratio & 42.911 & 15 & .000 \\
\hline Linear-by-Linear Association & 6.794 & 1 & .009 \\
\hline $\mathrm{N}$ of Valid Cases & 144 & & \\
\hline
\end{tabular}

From the results, a Chi-square value of 71.371 and a p-value of 0.000 were observed. Since the p-value of 0.000 is less than 0.05 , it therefore means that we reject the null hypothesis and conclude that there is a positive relationship between owner's innovation skills and the performance of women entrepreneurial ventures.

Table 4 presents Phi and Cramer's V test results on the strength of association between the tested variables.

Table 4. Symmetric measures

\begin{tabular}{|c|c|c|c|}
\hline & & Value & Approx. Sig. \\
\hline \multirow{2}{*}{ Nominal by Nominal } & Phi & .704 & .000 \\
\hline & Cramer's V & .406 & .000 \\
\hline \multicolumn{2}{|l|}{$\mathrm{N}$ of Valid Cases } & 144 & \\
\hline
\end{tabular}

Based on Phi test, it can be observed that the strength of association between the variables is strong $(0.704=70.4 \%)$. Given this strength of association, it can be concluded that there is a strong relationship between owner's innovation skills and the performance of women owned entrepreneurial ventures. These results are in line with those of Hameed and Ali (2011) who also tested the impact of innovation on the performance of women owned SMMEs in Somalia where the results also showed that innovation had a significant positive relationship with firm performance.

H3: The owners' ability to generate ideas does not play a role on the success of women owned enterprises. Chi-square test was conducted and the results are presented on Table 5. 
Table 5. Chi-Square tests for hypothesis 3

\begin{tabular}{|c|c|c|c|}
\hline & Value & Df & Asymp. Sig. (2-sided) \\
\hline Pearson Chi-Square & $66.429^{a}$ & 9 & .000 \\
\hline Likelihood Ratio & 60.475 & 9 & .000 \\
\hline Linear-by-Linear Association & 21.249 & 1 & .000 \\
\hline $\mathrm{N}$ of Valid Cases & 144 & & \\
\hline
\end{tabular}

From the results in Table 5, Chi-square value of 66.429 and a p-value of 0.00 was found. Since the p-value of 0.00 is less than 0.05 , it therefore means that we reject the null hypothesis and conclude that owners' ability to generate ideas plays a role on the success of women owned enterprises.

Table 6 presents results for the Phi and Cramer's V tests for the strength of association between owners' ability to generate ideas and the success of women owned enterprises.

Table 6. Symmetric measures

\begin{tabular}{l|l|c|c}
\hline \multicolumn{2}{|c}{} & Value & Approx. Sig. \\
\hline \multirow{2}{*}{ Nominal by Nominal } & Phi & .679 & .000 \\
\cline { 2 - 4 } & Cramer's V & .392 & .000 \\
\hline N of Valid Cases & & 144 & \\
\hline
\end{tabular}

Based on Phi, it can be observed that the strength of association between the variables is strong $(0.679=68 \%)$. We can therefore conclude that an owners' ability to generate ideas plays a positive role in the success of women owned enterprises. This is in line with a study conducted by Masood (2011) who found that innovative women have an ability to work hard. Their creative ideas are required to build up an enterprise. Jiang and Zimmernan (2012) also found that social and human competences were necessary for a successful start-up and growth of a women-owned business.

H4: Risk- taking has no contribution on the performance of entrepreneurial ventures owned by women. Chi-square test results are presented in Table 7.

Table 7. Chi-Square tests for hypothesis 4

\begin{tabular}{l|c|c|c}
\hline & Value & Df & Asymp. Sig. (2-sided) \\
\hline Pearson Chi-Square & $61.034^{\mathrm{a}}$ & 12 & .000 \\
\hline Likelihood Ratio & 72.393 & 12 & .000 \\
\hline Linear-by-Linear Association & 40.021 & 1 & .000 \\
\hline N of Valid Cases & 144 & & \\
\hline
\end{tabular}

From the results in Table 7, Chi-square value of 61.034 with a p- value of 0.00 was observed. Since the p-value of 0.00 is less than 0.05 , the null hypothesis is rejected and we can conclude that risk-taking has a positive contribution to the performance of entrepreneurial ventures owned by women.

Results for Phi and Cramer's V tests for the strength of association are presented in Table 8.

Table 8. Symmetric measures

\begin{tabular}{l|l|c|c}
\hline \multirow{2}{*}{ Nominal by Nominal } & Phi & Value & \multicolumn{2}{c}{ Approx. Sig. } \\
\cline { 2 - 4 } & Cramer's V & .651 & .000 \\
\hline N of Valid Cases & & .376 & .000 \\
\hline
\end{tabular}


Based on Phi, it can be observed that the strength of association between the variables is strong $(0.651=65 \%)$. Given this strength of association, it shows that risk-taking has a positive contribution on the performance of entrepreneurial ventures owned by women. These study findings are consistent with Michelmore and Rowley (2013) who pointed out that risk-taking is a critical entrepreneurial competency. Hameed and Ali (2011) also found that there is a significant positive relationship between risk-taking and firm performance.

H5: There is no relationship between owners' creativity and growth of women owned enterprises.

A Chi- square test was conducted and the results are presented in Table 9.

Table 9. Chi-Square tests for hypothesis 5

\begin{tabular}{l|c|c|c}
\hline & Value & Df & Asymp. Sig. (2-sided) \\
\hline Pearson Chi-Square & $42.134^{\mathrm{a}}$ & 9 & .000 \\
\hline Likelihood Ratio & 34.317 & 9 & .000 \\
\hline Linear-by-Linear Association & 11.065 & 1 & .001 \\
\hline N of Valid Cases & 144 & & \\
\hline
\end{tabular}

Based on the results presented in Table 9, a Chi-square value of 42.134 and a p-value of 0.00 were observed. Since the p-value of 0.00 is less than 0.05 , it therefore means that we reject the null hypothesis and conclude that there is a relationship between owners' creativity and growth of women owned enterprises.

Phi and Cramer's V tests for the strength of association are presented in Table 10.

Table 10. Symmetric measures

\begin{tabular}{|c|c|c|c|}
\hline & & Value & Approx. Sig. \\
\hline \multirow{2}{*}{ Nominal by Nominal } & Phi & .541 & .000 \\
\hline & Cramer's V & .312 & .000 \\
\hline \multicolumn{2}{|l|}{$\mathrm{N}$ of Valid Cases } & 144 & \\
\hline
\end{tabular}

Based on Phi, it can be observed that the strength of association between the variables is strong $(0.541=54 \%)$. Given this strength of association, it can be concluded that owner's creativity and the growth of women owned enterprises is moderate. Thus, if enterprises are to improve their performance, they need to continuously improve their existing products or services through innovation.

H6: The owners' ability of envisioning opportunities does not play a role in improving the performance of women entrepreneurs.

A Chi-square test was conducted and the results are presented in Table 11.

Table 11. Chi-Square tests for hypothesis 6

\begin{tabular}{|c|c|c|c|}
\hline & Value & Df & Asymp. Sig. (2-sided) \\
\hline Pearson Chi-Square & $22.043^{\mathrm{a}}$ & 9 & .009 \\
\hline Likelihood Ratio & 27.144 & 9 & .001 \\
\hline Linear-by-Linear Association & 4.919 & 1 & .027 \\
\hline $\mathrm{N}$ of Valid Cases & 144 & & \\
\hline
\end{tabular}

As can be observed on Table 11, a Chi-square value of 22.043 and a p-value of 0.00 were observed. Since the p-value is less than 0.05 , the null hypothesis is rejected. This tells us that there is statistically significant association between owners' ability of envisioning opportunities in improving the performance of women entrepreneurs. 
To test the strength of this association, Phi and Cramer's V tests were conducted and the results are presented in Table 12.

Table 12. Symmetric measures

\begin{tabular}{l|l|c|c}
\hline \multicolumn{2}{|c}{} & Value & Approx. Sig. \\
\hline \multirow{2}{*}{ Nominal by Nominal } & Phi & .391 & .009 \\
\cline { 2 - 4 } & Cramer's V & .226 & .009 \\
\hline \multirow{2}{*}{ N of Valid Cases } & & 144 & \\
\hline
\end{tabular}

Based on Phi, it can be observed that the strength of association between the variables is weak although it is statistically significant. Given this strength of association, it can be concluded that there is a relationship between owners' ability of envisioning opportunities and performance of women entrepreneurs. These findings are supported by Ahmad et al., (2010) who stated that there are three major roles an entrepreneur must play to ensure the success of their business, namely, opportunity recognition and exploitation, risk taking and innovation.

\section{CONCLUSION}

Based on the results obtained from the study, entrepreneurial competencies have an impact on the performance of women owned SMMEs in East London. Entrepreneurial competencies also play a role in the establishment and survival of SMMEs in East London. The study tested the effect of entrepreneurial competencies on various entrepreneurial skills. The study concluded that there is a significant relationship between idea generation, innovative skills, envisioning opportunities, creativity and risk-taking and the performance of women owned SMMEs in East London. Entrepreneurial competencies are also crucial for establishment and survival of SMMEs.

The role of SMMEs in the development of South Africa cannot be overlooked for SMMEs contribute significantly in employment creation as well as to the GDP of this country. Some recommendations are directed to the government, banks and other private organizations to assist in its efforts to develop the economy.

\section{RECOMMENDATIONS OF THE STUDY}

Based on the findings of this research, the following recommendations are suggested to SMMEs as to how they can improve their business performance. The SMME owners and managers are responsible for the performance of their businesses. They need to acquire skills that will improve their business performance. If women entrepreneurs intend to improve their entrepreneurial skills, they should always take advantage of skills development programmes offered by government agencies and institutions of higher learning. Through learning programs, entrepreneurs should enhance their entrepreneurial competencies to improve performance of their growth oriented businesses.

The government should also assist SMMEs by creating awareness of the support services available. The government should target potential entrepreneurs and equip them with skills on how to become employment creators.

\section{LIMITATIONS OF THE STUDY}

The study was only limited to women owned SMMEs operating in East London, South Africa. Quantitative research design was used in this study and all the limitations associated with this design apply to this research. Since this study was limited to one municipality, it is difficult to generalise the findings to the whole of South Africa.

\section{REFERENCES}

Ahmad, N. H., Ramayah. T., Wilson, C. \& Kummerow, L. (2010). Is entrepreneurial competency and business success relationship contingent upon business environment? International Journal of entrepreneurial Behaviour \& Research, 16(3), 182-203.

Ahmand, N. H., Halim, H. A. \& Zainal, S. R. M. (2010). Is entrepreneurial competency the silver Bullet for SME success in a Development Nation? Interdisciplinary Journal of contemporary Research in Business, 2(1), 217-236. 
Ali, A. Y. S. \& Ali, A. H. (2014). Entrepreneurial Orientation and performance of women owned and managed micro and small enterprises in Somalia. Zenith International Journal of Multidisciplinary Research, 4(1), 2231-5780.

Amoah-Mensah, A. (2013). Strategic resources and performance of rural SMEs. International Journal of Business and Social Research, 3(4), 106-119.

Arroyo, M. R., Feuntes, M. M., Bojica, A. M. \& Ariza, L. R. (2012). Innovativeness and performance in women-owned small firms: The knowledge of acquisition. Journal of small business and entrepreneurship, 25(3), 307-326.

Ayyagari, M., Demirguc-Kunt, A. \& Maksimovic, V. (2011). Small vs. young firms across the world contribution to employment, job creation, and growth. Policy Research Working Paper, 563.

Botha, M. \& Nyanjam, M. D. O. (2011). Corporate entrepreneurship orientation and pursuit of innovating opportunities in Botswana. Acta Commercii, (11), 30-44.

Brijlal, P., Naicker, V. \& Peter, V. (2013). Education and SMMEs business growth: A gender perspective from South Africa. International Business and Economics Research Journal, 12(8), 855-866

Brisk, L. (2002). Formal entrepreneurial mentoring: The efficiency of third party managed programmes. Career Development International, 7(5), 262-270.

Camuffo, A., Fabrizo, G. \& Gubitta, P. (2012). Competencies matter: Modelling effective entrepreneurship in North east of Italy small firms. Cross cultural management, 19(1), 48-66.

Chiloane-Tsoka, E. \& Mello, D. M. (2011). Government mentorship programmes for women entrepreneurs in Tshwane, South Africa. Journal of Public Administration, 46(4), 1445-1458

Chiloane-Tsoka, E. (2013). Investigation into the financial barriers facing women entrepreneurs operating in SMMEs in Tshwane, South Africa. Journal of Economic and Financial Sciences, 6(2), 347-358.

Dafna, K. (2008). Managerial performance and business success gender differences in Canadian and Israeli entrepreneurs. Journal of Enterprising Communities, 2(4), 300-331.

Du Toit, G. S., Erasmus, B. J. \& Strydom, J. W. (2010). Introduction to business management. 8th Edition. Oxford, Southern Africa.

Fatoki, O. \& Garwe, D. (2010). Obstacles to the growth of SMEs in South Africa: A principal component analysis approach. African Journal of Business Management, 4(5), 729-738.

Fatoki, O. \& Machirori, T. L. (2013). The impact of networking an access to debt finance and performance of small and medium enterprises South Africa. Journal of Economics, 4(2), 97-104.

Fatoki, O. \& Odeyemi, A. (2010). Which new small and medium enterprises in South Africa have access to bank credit? International Journal of Business and Management, 5(10),128-136.

Fortkamp, U. \& Staffas, L. (2012). Integration of sustainability aspects in innovation process. IVL Swedish Environmental Research Institution Ltd IVL report B2025

Goyal, M. \& Parkash, M. (2011). Women entrepreneurial in India-problems and prospects. International Journal of Multidisciplinary Research, 1(5), 2231-5780.

Hameed, I. \& Ali, B. (2011). Impact of Entrepreneurial orientation, entrepreneurial management and environmental dynamism on firm's financial performance. Journal of Economics and Behavioral Studies, 3(2), 101-114.

Hansen, D. J., Lumpkin, G. L. \& Hills, G. (2011). A multidimensional examination of creativity-based opportunity recognition model. International Journal of Entrepreneurial Behaviour and Research, 17(5), 515-533.

Hendriks, S. L., van der Merwe, C., Ngidi, M. S., Manyamba, C., Mbele, M., Mclntyre, A. M., ... \& Ngwane, L. (2016). What are we measuring? Comparison of household food security indicators in the Eastern Cape, South Africa. Ecology and Food Nutrition, 55(2), 141-162.

Herrington, M., Kew, J \& Kew, P. (2010). Global Entrepreneurship Monitor, South African report. (Online) Available: http://www.gsb.uct.ac.za/files/GEM2010Report.pdf [Accessed 29 March 2014].

Jiang, C. X. \& Zimmernan, M. A. (2012). Growth of women-owned businesses: The effects of tangible resources and social competence perspective, Entrepreneur's competences business faculty publications. Journal of business Diversity, 12 (1), 47-71.

Kimwolo, A. K., Saina, C. K. \& Cheserek, G. J. (2012). Effects of credit training skills on sales performance among women entrepreneurs in Elgeiyo Marakwet Country, Kenya. Journal of Emerging Trends in Economics and Management Science, 3(6), 945-950.

Machirori, T. L. (2012). The impact of networking on access to finance and performance of SMEs in the Buffalo City Municipality, Eastern Cape, South Africa. Unpublished Dissertation. Available from the University of Fort Hare, South Africa.

Mahmood, R. \& Hanafi, N. (2013). Entrepreneurial Orientation and Business Performances of women-owned Small and medium Enterprises in Malaysia: Competitive advantage as a mediator. International Journal of Business and Social Science, 4(1), 82-90.

Maloka, C. M. (2013). The contribution of small and micro enterprise towards local economic development in Mankweng Township, Limpopo province. Unpublished Dissertation. Available from the University of Limpopo, South Africa.

Mandipaka, F. (2014). Overview of women entrepreneurs in South Africa. Mediterranean Journal of Social Sciences, 5(9), 127130 . 
Masood, R. Z. (2011). Emergence of women- entrepreneurs businesses in India- An insight. Journal of Arts Science and Commerce, 2(1), 233-243.

Mbonyane, B. \& Ladzani, W. (2010). Factors that hinder the growth of small businesses in South African townships. European Business Review, 23(6), 550-560.

Mehta, P. (2013). Women entrepreneurship: Purpose, problems, and prospects. A study of Udaipur District. Pacific Business Review International, 5(11), 8-16.

Mitchelmore, S. \& Rowley, J. (2010). Entrepreneurial competencies: a literature review and development agenda. International Journal of Enterprise Behaviour and Research, 16(2), 92-111.

Mitchelmore, S. \& Rowley, J. (2013). Entrepreneurial competencies of women entrepreneurs pursuing business growth. Journal of Small Business and Enterprise Development, 1(11), 125 -142.

Mitchelmore, S. \& Rowley, J. (2013). Growth and planning strategies within women-led SMEs. Management Decision, 5(1), 8396.

Mmbengwa, V. M., Ramukumba, T., Groenewald, J. A., Van Schalkwyk, M. B., Gundidzo, M. B. \& Maiwashe, A. N. (2012). Analysis of the socio-economic factors that contribute to land and agrarian reform which initiated and supported small, micro, medium farming enterprises (SMMEs) in South Africa. African Journal of Business Management, 6(24), 158169.

National Small Business Act. (1996). Office of the President of South Africa. Pretoria.

Peter, R. \& Naicker, V. (2013). Small medium micro enterprises business goals and government support: A South African case study. South African Journal Business Management, 44(4), 13-24.

Peters, D. (2013). Gender and sustainable urban mobility. Thematic study prepared for Global Report on Human Settlements. Nairobi. Available: http://www.unhabitat.org/grhs/2013

Phan, P., Zhou, J. \& Abrahamson, E. (2010). Creativity, Innovation, and entrepreneurship in China. Management and Organization Review, 6(2), 175-194.

Pretorius, M., Millard, S. M. \& Kruger, M. E. (2005). Creativity, innovation and implementation: Management experience, venture size, life stage, race and gender as moderations. South African Journal Business Management, 36(4), 55-68.

Raosoft (2011). Sample size calculator. Online available: http://www.raosoft.com/samplesize.html. [Accessed: 24 June 2014]

Santandreu-Mascarell, C., Garzon, D., Knorr, H. Entrepreneurial and innovative competencies, are they the same? Management Decision, 54(5): 1084-1095.

Sharma, Y. (2013). Women entrepreneurs in India. Journal of Business and Management, 15(3), 09-14.

Song, H. N. \& Kee, D. M. H. (2013). Effect of entrepreneurial competencies on the performance under the influence of organizational culture. Life Sciences Journal, 10(4), 2459-2466.

Taatila, V. P. (2010). Learning entrepreneurship in higher education. Education and Training, 52(1), 48-61.

Toner, P. (2011). Workforce skills and innovation: An overview of major themes in the literature. Centre for industry and innovation studies. University of Western Sydney: Australia.

Urban, B. \& Naidoo, R. (2012). Business sustainability: Empirical evidence on operational skills in SMEs in South Africa. Journal of Small Business Enterprise Development, 19(10), 146-163.

Van Scheers, L. (2011). SMEs marketing skills challenges in South Africa. African Journal of Business Management, 5(13), 5048-5056.

Viju, M. (2010). Women entrepreneurship in Middle East: Understanding barriers and use of ICT for entrepreneurship development. International Entrepreneurship Management Journal, 6, 163-181.

Xavier, S. R., Ahmad, S. Z., Nor, L. M. \& Yusuf, M. (2012). Women entrepreneurs: Making a change from employment to small and medium business ownership. Procedia Economics and Finance, 4, 321-333. 
NOTES 